Pawet FUC

Joanna TOMANKIEWICZ

Rafat ZYBALA

Juliusz LESZCZYŃSKI

Piotr LIJEWSKI

Pawet NIERODA

\title{
Prototypical thermoelectric generator for waste heat conversion from combustion engines
}

\begin{abstract}
The work presents experimental results of performance tests and theoretical calculations for the thermoelectric generator TEG fitted in the exhaust system of a $1.3 \mathrm{dm}^{3}$ JTD engine. Benchmark studies were carried out to analyze the performance of the thermoelectric modules and total TEG efficiency. Additionally the investigation of combustion engine's power drop casued by exhaust gases flow resistance is presented. The detailed studies were performed using a new prototype of the thermoelectric generator TEG equipped with 24 BiTe/SbTe modules with the total nominal power of $168 \mathrm{~W}$. The prototypical device generates maximal power of $200 \mathrm{~W}$ for the exhaus gases mass flow rate of $170 \mathrm{~kg} \cdot \mathrm{h}^{-1}$ and temperature of $280^{\circ} \mathrm{C}$. Power drop caused by the flow resistance of gases ranges between 15 and 35 mbar for mass flow rate 100-180 $\mathrm{kg} \cdot \mathrm{h}^{-1}$. We predict that the application of the new thermoelectric materials recently developed at AGH would increase the TEG power by up to $1 \mathrm{~kW}$, would allow the increase of the powertrain system efficiency by about $5 \%$, and a corresponding reduction of $\mathrm{CO}_{2}$ emission.
\end{abstract}

Keywords: waste heat recovery, thermoelectric generator, thermoelectric module, energy conversion

\section{Prototypowy generator termoelektryczny do konwersji odpadowej energii cieplnej z silników spalinowych}

\begin{abstract}
W pracy przedstawiono wyniki badań eksperymentalnych i obliczeń teoretycznych dla generatora termoelektrycznego TEG zaimplementowanego w ukladzie wylotowym silnika 1,3 JTD. Badania przeprowadzono w celu analizy sprawności modułów termoelektrycznych oraz całkowitej sprawności generatora TEG. Dodatkowo w pracy zaprezentowano badania strat mocy silnika spowodowane oporem przepływu gazów wylotowych. Szczegółowe badania przeprowadzono przy użyciu nowego prototypu generatora termoelektrycznego TEG wyposażonego w 24 moduly BiTe/SbTe o tącznej mocy $168 \mathrm{~W}$. Badany generator wytwarza moc maksymalna $200 \mathrm{~W}$ przy temperaturze $280^{\circ} \mathrm{C}$ i masowym natężeniu przepływu gazów wylotowych $170 \mathrm{~kg} \cdot h^{-1}$. Wymiennik ciepła generatora TEG wywołuje opory przepływu gazów w zakresie 15-35 mbar dla natężén przepływu 100-180 kg $\cdot h^{-1}$. Przewidywane jest również zastosowanie opracowanych na AGH nowych materiałów termoelektrycznych, które umożliwiłoby zwiększenie mocy generatora do $1 \mathrm{~kW}$, podniesienie całkowitej sprawności uktadu napędowego o ok. $5 \%$ i odpowiednie zmniejszenie emisji $\mathrm{CO}_{2}$.

Słowa kluczowe: odzysk ciepła odpadowego, generator termoelektryczny, moduł termoelektryczny, konwersja energii
\end{abstract}

\section{Introduction}

One of the primary problems the world is facing today is the growing demand for energy. This issue is of particular importance in the context of rapidly depleting resources of fossil fuels such as oil, coal or natural gas. As a result of continuous increase of fuel consumption not only the emission of greenhouse gases is increasing but also the costs of energy production. Therefore, for the sake of sustainable technological development it is necessary to limit the use of natural resources meanwhile investing in the development of renewable energy technologies. It should be noted that commercially produced energy is used inefficiently - most of it is wasted and irretrievably dissipated in the environment.

For instance contemporary car engines exchange app. $30-40 \%$ of heat generated in the process of fuel combustion into useful mechanical work. The remaining heat is

\section{Wprowadzenie}

Jednym z podstawowych problemów na świecie jest rosnące zapotrzebowanie na energię. Kwestia ta ma szczególne znaczenie w kontekście szybkiego wyczerpywania się zasobów paliw kopalnych, takich jak ropa naftowa, węgiel lub gaz ziemny. Wynikiem ciąglego wzrostu zużycia paliwa jest nie tylko zwiększenie emisji gazów cieplarnianych, ale także wzrost kosztów produkcji energii. Dlatego, w trosce o zrównoważony rozwój technologiczny konieczne jest ograniczenie wykorzystania zasobów naturalnych w międzyczasie inwestując w zrównoważony rozwój energii odnawialnej. Należy zauważyć, że energia produkowana komercyjnie jest wykorzystywana nieefektywnie większość energii jest traktowana jako odpad i nieodwracalnie rozpraszana w otoczeniu.

Współczesny silnik spalinowy zamienia 30-40 \% energii cieplnej wytworzonej w procesie spalania paliwa w użytecz- 
emitted to the environment through the exhaust gases and the engine cooling systems. It is estimated that the thermal energy contained in the exhaust gases of modern internal combustion engines SI and CI is approximately $25-35 \%$ of the total heat derived from the combustion of fuel. Therefore, even a partial use of the wasted heat would allow a significant improvement of the overall combustion engine performance. Conversion of the heat energy of the exhaust gases into electrical power would bring measurable advantages. It is commonly assumed that the application of thermoelectric generators TEG for waste heat recovery in automotive exhaust systems would permit lowering of the fuel consumption by even 5 to $10 \%[1,2]$.

\section{Principle of operation of thermoelectric modules}

Thermoelectric materials are used in the two groups of thermoelectric devices: Peltier modules for cooling and in thermoelectric generators. Thermoelectric generators TEG convert heat directly into electricity as a result of the thermoelectric effect. This effect was discovered by the German physicist Thomas Seebeck in 1821. The Seebeck effect is a phenomenon in which voltage is generated in a closed circuit composed of two different metals or semiconductors (Fig. $1 \mathrm{~A}$ and $\mathrm{B})$, called the thermocouple, as a result of different temperatures at the materials junctions.

In practical applications hundreds of thermocouples make the thermoelectric modules of which the thermoelectric generators TEG consist. Figure 2 shows a scheme of the thermoelectric module consisting of $p$ and n-type thermoelectric materials connected by metallic interconnectors.

Semiconductor elements are placed between the ceramic plates which perform the function of both the insulator and the module housing. One side of those semiconductors is heated and the other serves as a radiator. The resulting temperature gradient between the junctions creates an electric potential difference.

If the electrical circuit is closed by an external electrical load (e.g. resistor, bulb) an electric current appears. Commercially available TE modules are typically of a flat rectangular shape of the ceramic plates and are made of semiconductor thermoelectric materials (usually alloys of $\mathrm{Bi}_{2} \mathrm{Te}_{3}$ and $\mathrm{Sb}_{2} \mathrm{Te}_{3}$ ). The type of the used materials determines the temperature range and effectiveness of thermal energy conversion. The ef-

Fig. 1. Diagram of the thermocouple consisting of two different thermoelectric materials A and B. As a result of temperature difference $T_{H}-T_{C}$ the output voltage is generated

Rys. 1. Schemat termopary sktadajacej się z dwóch różnych materiałów termoelektrycznych: A i B. W wyniku różnicy temperatur $T_{H}-T_{C}$ jest generowane napięcie

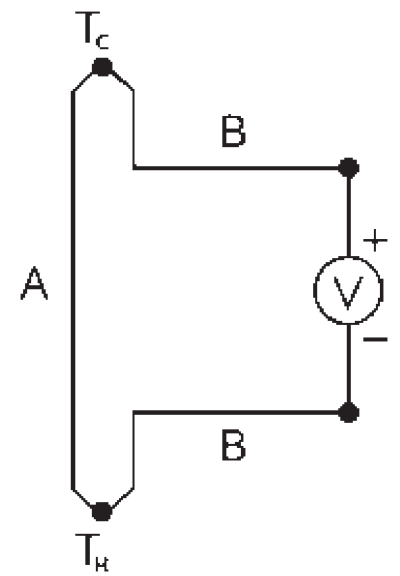

ną pracę mechaniczną. Pozostałe ciepło jest emitowane do środowiska przez gazy wylotowe i układ chłodzenia silnika. Szacuje się, że energia cieplna zawarta w gazach wylotowych nowoczesnych silników o ZI i ZS stanowi 25-35 \% całkowitego ciepła pochodzącej ze spalania paliwa. W związku z tym, nawet częściowe wykorzystanie traconego ciepła umożliwi znaczną poprawę sprawności ogólnej silnika spalinowego. Konwersja energii cieplnej z gazów wylotowych w energię elektryczną może przynieść wymierne korzyści. Powszechnie przyjmuje się, że zastosowanie generatorów termoelektrycznych TEG do odzysku ciepła w układach wylotowych pojazdów pozwoli na obniżenie zużycia paliwa nawet o 5-10\% $[1,2]$.

\section{Zasada dzialania modulów termoelektrycznych}

Materiały termoelektryczne wykorzystywane są w dwóch rodzajach urządzeń termoelektrycznych: w modułach chłodzących Peltiera oraz w generatorach termoelektrycznych. Generatory termoelektryczne TEG zamieniają ciepło bezpośrednio w energię elektryczną z wykorzystaniem efektu Seebecka. Efekt ten został odkryty przez niemieckiego fizyka Thomasa Seebecka w 1821 roku. Zjawisko Seebecka jest zjawiskiem, w którym generowane jest napięcie w obwodzie zamkniętym, złożonym z dwóch

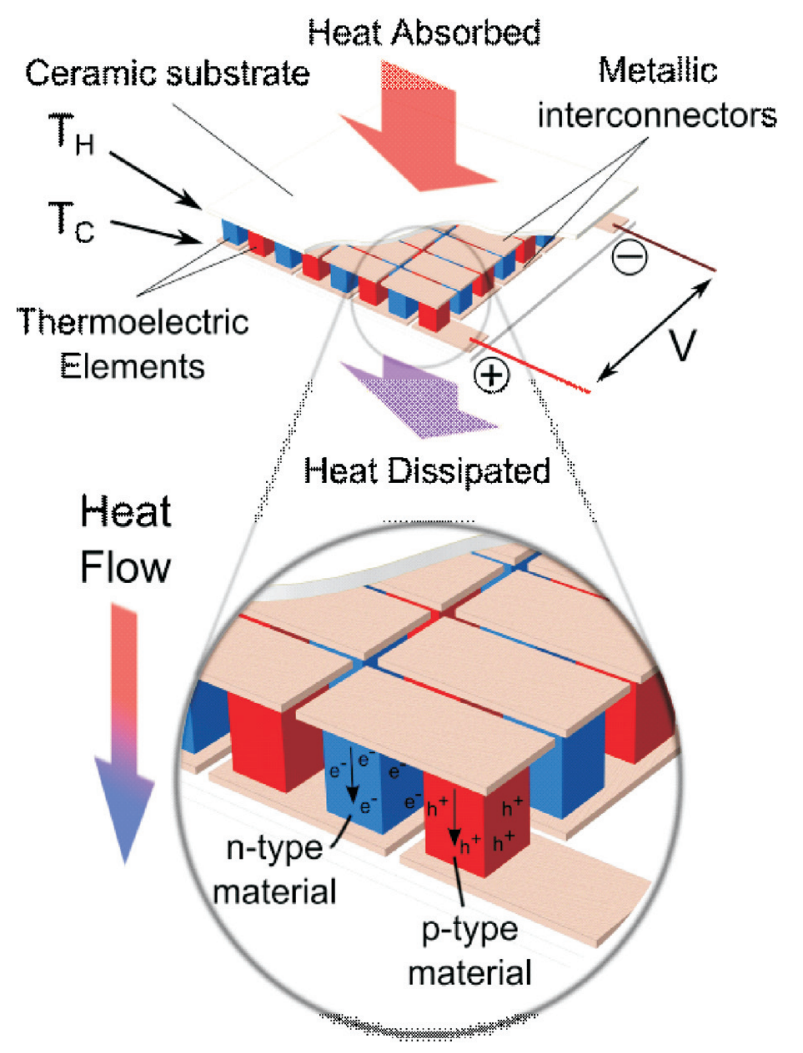

Fig. 2. A scheme of the TE module consisting of $p$ and n-type thermoelectric elements connected by metallic interconnectors

Rys. 2. Schemat modułu termoelektrycznego składającego się z elementów termoelektrycznych typu p i n, połaczonych metalowymi interkonektorami 
ficiency of thermoelectric modules $\eta_{\mathrm{g}}$ depends both on the Carnot efficiency $\eta_{\mathrm{c}},=\left(\mathrm{T}_{\mathrm{H}}-\mathrm{T}_{\mathrm{C}}\right) / \mathrm{T}_{\mathrm{C}}$, as well as the materials properties, and can be estimated from the equation:

$$
\eta_{\mathrm{g} \max }=\frac{\mathrm{T}_{\mathrm{H}}-\mathrm{T}_{\mathrm{C}}}{\mathrm{T}_{\mathrm{C}}} \cdot \frac{\sqrt{1+\mathrm{ZT}}-1}{\sqrt{1+\mathrm{ZT}}+\frac{\mathrm{T}_{\mathrm{C}}}{\mathrm{T}_{\mathrm{H}}}}
$$

where: ZT parameter, called the nondimensional thermoelectric figure of merit, can be calculated from the equation:

$$
\mathrm{ZT}=\frac{\alpha^{2} \sigma}{\lambda} \cdot \mathrm{T}_{\mathrm{aver}}
$$

From this equation it can be concluded that a good thermoelectric material should be characterized by a high Seebeck coefficient $\alpha$, high electrical conductivity $\sigma$ and low thermal conductivity $\lambda$.

\section{Construction of the TEG generator}

In the construction of thermoelectric generators, we can distinguish two main components: heat exchanger and thermoelectric modules, which are the essential part of the TEG. The heat is absorbed from hot gases by a suitably designed heat exchanger HX and transferred to thermoelectric modules. The heat flux passing through the TE modules is partly converted to electric energy and the rest of the heat is dissipated to the heat sinks (coolers). While designing a TEG system the geometry of the heat exchanger and the type of modules must be chosen depending on the temperature and the mass flow of exhaust gases. Due to a simple construction and lack of moving parts TEG shows a number of highly desired features in modern technologies, like: high durability and reliability, low mass, noiseless operation. Due to their advantages they are applied in maintenance free devices such as space probes (e.g. Voyager missions, Curiosity rover), weather stations or in military equipment.

In our previous studies [3] we have constructed and examined a prototypical TEG which had a rectangular cross-section geometry of the heat exchanger, similar to the first device by Birkholz et al. [2]. The generator was used for comparison of waste-heat recovery capabilities in typical combustion engines used in automotive vehicles: spark ignition SI and compression ignition CI engine [3]. That TEG generator was characterized by its simple design and low costs of manufacturing. However, our tests revealed it had some disadvantages, such as: non-optimal usage of thermal power received from the exhaust gases (too low nominal power of the installed modules in respect to the heat captured in HX), non-uniform temperature distribution along the heat exchanger and large asymmetry in temperatures between the upper and lower side of the heat exchanger.

Taking the first tests results and general considerations for TEG construction into account, we have designed a new prototype consisting of heat exchanger with a hexagonal geometry of the gas channel and a corresponding symmetry of fins pattern. This construction is similar to the one proposed różnych metali lub półprzewodników (rys. 1 A i B), dzięki utrzymaniu złącz pomiędzy tymi materiałami w różnych temperaturach.

W praktycznych zastosowaniach moduły termoelektryczne z których zbudowane są generatory termoelektryczne TEG składają z setek termopar. Rysunek 2 przedstawia schemat jednostopniowego generatora termoelektrycznego, składającego się z materiałów termoelektrycznych typu $\mathrm{p}$ i n połączonych metalowymi łącznikami.

Elementy półprzewodnikowe umieszczone są pomiędzy płytkami ceramicznymi, które pełnią funkcję zarówno izolatora jak i obudowy modułu. Po jednej stronie półprzewodniki ogrzewane są za pomocą źródła ciepła natomiast z drugiej strony chłodzone są za pomocą chłodnicy. Gradient temperatury powstały pomiędzy złączami prowadzi do powstania różnicy potencjału elektrycznego. W momencie zamknięcia obwodu elektrycznego przy przyłączeniu zewnętrznego obciążenia (np. opornik albo żarówka) w obwodzie pojawia się prąd elektryczny.

Komercyjnie dostępne moduły TE mają zazwyczaj kształt płaskich prostokątnych płytek ceramicznych i wykonane są z półprzewodnikowych materiałów termoelektrycznych (zwykle stopów $\mathrm{Bi}_{2} \mathrm{Te}_{3} \mathrm{i} \mathrm{Sb}_{2} \mathrm{Te}_{3}$ ). Rodzaj zastosowanych materiałów termoelektrycznych ma wpływ na zakres temperatur oraz wydajność konwersji energii. Sprawność generatorów termoelektrycznych ๆc zależy od sprawności Carnota $\eta_{\mathrm{c}}=\left(\mathrm{T}_{\mathrm{H}}-\mathrm{T}_{\mathrm{C}}\right) / \mathrm{T}_{\mathrm{C}}$ oraz od właściwości materiałów termoelektrycznych, które zostały użyte. Można ją obliczyć na podstawie równania (1),

gdzie parametr ZT, jest bezwymiarowym współczynnikiem efektywności termoelektrycznej i może być obliczony z równania (2).

$\mathrm{Z}$ powyższego równania wynika, że dobry materiał termoelektryczny powinien charakteryzować się wysokim współczynnikiem Seebecka $\alpha$, wysoką przewodnością elektryczną $\sigma$ i niską przewodnością cieplną $\lambda$.

\section{Konstrukcja generatora}

W konstrukcji generatorów termoelektrycznych wyróżnia się dwa główne elementy: wymiennik ciepła oraz moduły termoelektryczne, które są zasadniczym elementem TEG. Energia cieplna odbierana z gazów wylotowych przez specjalnie zaprojektowany wymiennik ciepła HX przepływa do modułów termoelektrycznych. Ciepło przechodzące przez moduły termoelektryczne jest częściowo przetwarzane na energię elektryczną, natomiast pozostałe ciepło przenoszone jest do chłodnicy. Kluczowym zagadnieniem pojawiającym się podczas projektowania systemu TEG jest dopasowanie wymiennika ciepła oraz modułów termoelektrycznych do spodziewanego natężenia przepływu oraz temperatury gazów wylotowych.

Ze względu na prostą konstrukcję i brak części ruchomych generator TEG wykazuje szereg cech pożądanych we współczesnych technologiach, takich jak: wysoka wytrzymałość, niezawodność, niska masa, bezgłośna praca oraz możliwość wykorzystania w maszynach, które nie wymagają dodatkowej obsługi przez człowieka. Ze względu na swoje zalety generatory TEG są używane w maszynach, takich jak 
by Bass et al. [4]. Theoretically, the new heat exchanger geometry should allow almost 3 -fold increase in the number of TE modules compared to the same inner heat exchange surface in the previous prototype. This should lead to a proportional increase of power and efficiency while maintaining similar dimensions of the generator.

Figures 3 and 4 present drawings of the constructed TEG prototype. The heat exchanger was made of aluminium, because of its specific advantages such as: high thermal conductivity, low specific weight and relatively good resistance against corrosion caused by the exhaust gases in temperatures up to $300{ }^{\circ} \mathrm{C}$.

In order to enhance the heat transfer longitudinal fins were used on the entire length of the HX chamber. To improve temperature uniformity along the exchanger, which was a problem in our previous prototype, variable height of the ribs was used. The generator contains 24 commercial TE

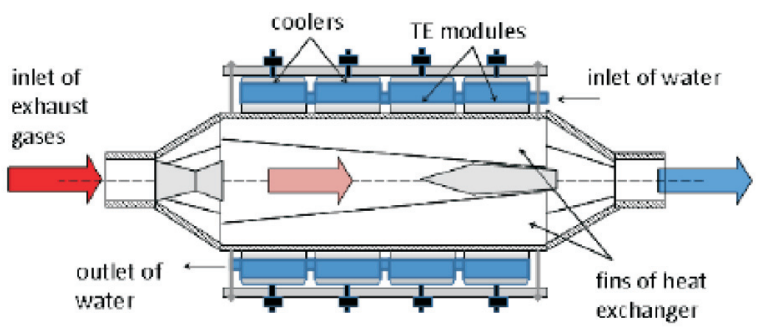

Fig. 3. Schematic cross-section of the thermoelectric generator Rys. 3. Schemat przekroju poprzecznego generatora termoelektrycznego

modules based on $\mathrm{Bi}_{2} \mathrm{Te}_{3}-\mathrm{Sb}_{2} \mathrm{Te}_{3}$ thermoelectric materials, mounted between the heat exchanger and the coolers. Each module has a separate liquid cooler fixed using a binding screw which simultaneously tightens the module to the heat exchanger. The coolers can use water or typical automotive coolants e.g. from an external cooling system of the car engine.

\section{Experimental procedure}

The TEG generator was fitted between the exhaust aftertreatment system and the outlet of exhaust gases of a $1.3 \mathrm{dm}^{3}$ CI engine, which met the Euro 4 emission standards.

Because of the temperature range specific to the applied $\mathrm{BiSb} / \mathrm{BiTe}$ modules (Table 1) the generator was placed in the part of exhaust tube in which temperatures of the exhaust gases did not exceed $300^{\circ} \mathrm{C}$. The whole combustion engine - TEG generator system was tested on a test cell (Fig. 5) equipped with Automex dynamometer, ABB SensyFlow airflow meter and two UMT 65 pressure sensors which measured the drop of the pressure. The temperature distribution across the heat exchanger was measured by thermocouples attached close to the hot and cold sides of the thermoelectric elements. The coolant flow rates, as well as its temperatures on inlets and outlets of coolers were measured to calculate the amount of heat absorbed by the heat exchanger. The voltages and currents in the each of the electrical sections were measured separately. sondy kosmiczne (misje Voyager, łazik Curiosity), stacje pogodowe, czy urządzenia wojskowe.

W poprzednich pracach opisano skonstruowany i przebadany prototypowy generator TEG z wymiennikiem ciepła o przekroju prostokątnym, podobnym do urządzenia zbudowanego przez Birkholza [2]. Ten generator wykorzystano do analizy możliwości odzysku ciepła odpadowego z dwóch typów silników spalinowych: o zapłonie iskrowym i samoczynnym [3]. Generator TEG charakteryzował się prostą konstrukcją a zarazem niskimi kosztami wytworzenia. Podczas testów zaobserwowano również wady takie jak: nieoptymalne wykorzystanie mocy odbieranej od gazów wylotowych (zbyt niska moc zainstalowanych modułów termoelektrycznych w stosunku do ilości ciepła odbieranego przez wymiennik), nierównomierny rozkład temperatur wzdłuż osi wymiennika i wysoka różnica temperatur pomiędzy górną i dolną częścią generatora.

Biorąc pod uwagę pierwsze wyniki prac badawczych i ogólne założenia konstrukcji TEG, zaprojektowano nowy prototyp złożony z wymiennika ciepła o przekroju heksagonalnym z symetrycznie rozłożonymi żebrami. Konstrukcja ta podobna jest do zaproponowanej przez Bassa [4]. Zmiana ta pozwoliła na trzykrotne zwiększenie ilości zamontowanych modułów TEG w porównaniu do tej samej wewnętrznej powierzchni wymiennika ciepła w poprzednim prototypie. Umożliwiło to proporcjonalny wzrost mocy i sprawności przy zachowaniu podobnych wymiarów zewnętrznych generatora.

Rysunki 3 i 4 przedstawiają schematy skonstruowanego prototypowego TEG. Wymiennik ciepła wykonano z aluminium, ze względu na specyficzne zalety tego materiału, takie jak: wysokie przewodnictwo cieplne, niski ciężar i względną odporność na korozję powodowaną przez gazy wylotowe w temperaturach do $300{ }^{\circ} \mathrm{C}$.

Na całej długości wymiennika umieszczono żebra w celu poprawienia sprawności wymiany ciepła. Ponadto, dla poprawy jednorodności temperatury wzdłuż wymiennika, co było problemem w poprzednim prototypie, zastosowano zmienną geometrię żeber. Generator zawiera 24 komercyjne moduły TE oparte na materiałach termoelektrycznych

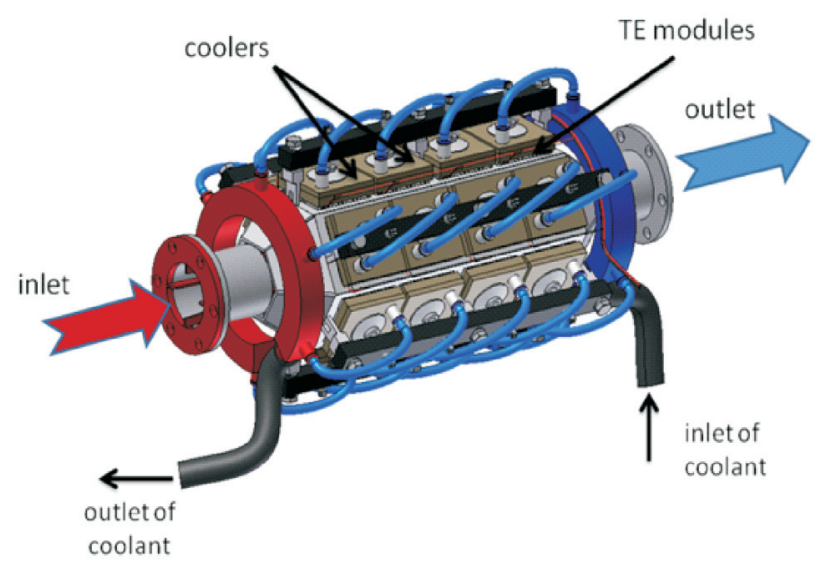

Fig. 4. View of the thermoelectric generator TEG Rys. 4. Widok generatora termoelektrycznego TEG 
Table 1. Parameters of the thermoelectric generator TEG Tablica 1. Parametry generatora termoelektrycznego TEG

\begin{tabular}{|c|c|}
\hline Total dimensions/wymiary całkowite & $280 \mathrm{~mm} \times 555 \mathrm{~mm}$ \\
\hline $\begin{array}{l}\text { Dimensions of the heat exchanger/wymiary } \\
\text { wymiennika ciepta }\end{array}$ & $110 \mathrm{~mm} \times 311 \mathrm{~mm}$ \\
\hline $\begin{array}{l}\text { Inner surface of the heat exchange/wewnettrz- } \\
\text { na powierzchnia wymiennika ciepta }\end{array}$ & $0.574 \mathrm{~m}^{2}$ \\
\hline $\begin{array}{l}\text { Material of the heat exchanger/materiat } \\
\text { wymiennika ciepta }\end{array}$ & $\begin{array}{l}\text { Aluminium alloy/ } \\
\text { stop aluminium }\end{array}$ \\
\hline $\begin{array}{l}\text { Number of TE modules/ilość modułów } \\
\text { termoelektrycznych }\end{array}$ & 24 \\
\hline $\begin{array}{l}\text { Nominal power of a single TE module/ moc } \\
\text { nominalna jednego modułu TE }\end{array}$ & $\begin{array}{c}7 \mathrm{~W}\left(\mathrm{Tc}=50^{\circ} \mathrm{C}\right. \\
\left.\mathrm{T}_{\mathrm{H}}=175^{\circ} \mathrm{C}\right)\end{array}$ \\
\hline $\begin{array}{l}\text { Total nominal power of TE modules/catkowi- } \\
\text { ta moc nominalna modułów TE }\end{array}$ & $168 \mathrm{~W}$ \\
\hline $\mathrm{U}_{\mathrm{oc}}$ voltage $\left(\mathrm{T}_{\mathrm{in}}=250^{\circ} \mathrm{C}\right) /$ napięcie & $280 \mathrm{~V}$ \\
\hline $\begin{array}{l}\text { Max. operating temperature of TE modules/ } \\
\text { maksymalna temperature pracy modulów }\end{array}$ & $200{ }^{\circ} \mathrm{C}$ \\
\hline Total mass/calkowita masa & $\sim 1260 \mathrm{~g}$ \\
\hline
\end{tabular}

The characterization of the TEG parameters was carried out at engine speeds and torques similar to these occurring in the real road conditions typical for this engine (1800-2600 rpm, 12-135 N.m, respectively). Table 2 contains selected parameters of $1.3 \mathrm{dm}^{3}$ Diesel engine which is typical for a medium-size car.

Table 2. Characteristic of the 1.3 JTD engine

Tabela 2. Charakterystyka silnika 1,3 JTD

\begin{tabular}{|c|c|}
\hline Engine/silnik & $1.3 \mathrm{JTD}$ \\
\hline $\begin{array}{c}\text { Cylinders/capacity/cylindry/ } \\
\text { pojemność }\end{array}$ & $4 / 1.3 \mathrm{dm}^{3}$ \\
\hline Valves/zawory & 16 \\
\hline Injection system/uktad wtryskowy & common rail \\
\hline Engine power/moc silnika & $51 \mathrm{~kW} @ 4000 \mathrm{rpm}$ \\
\hline Torque/moment obrotowy & $180 \mathrm{~N} \cdot \mathrm{m} @ 1750 \mathrm{rpm}$ \\
\hline $\begin{array}{c}\text { Max. flux of exhaust gases/maksy- } \\
\text { malny przeptyw gazów spalinowych }\end{array}$ & $\sim 220 \mathrm{~kg} / \mathrm{h}$ \\
\hline
\end{tabular}

\section{Theoretical calculations of exhaust gases flow resistance}

The presence of the TEG generator in the exhaust system of the combustion engine causes the increase of resistance of the exhaust gas flow and has direct influence on the drop of the engine power. The increased resistance of the gas flow through the heat exchanger can be estimated from pressure drop before and after the TEG generator. The idea of this calculation is presented in the Fig. 6.

The power losses associated with the pressure drop can be calculated from the equation:

$$
\mathrm{P}_{\text {loss }}=\Delta \mathrm{p} \cdot \mathrm{V}_{\mathrm{vol}}
$$

The flow resistance was estimated using two methods: analytical method (which is commonly applied for modelling
$\mathrm{Bi}_{2} \mathrm{Te}_{3}-\mathrm{Sb}_{2} \mathrm{Te}_{3}$, zainstalowane między wymiennikiem ciepła a chłodnicami. Każdy moduł jest przymocowany do oddzielnej chłodnicy za pomocą śruby dociskowej, która jednocześnie służy do przytwierdzenia modułu do wymiennika ciepła. Jako czynnik chłodzący zastosowano wodę lub ciecz chłodzącą używaną w zewnętrznym układzie chłodzenia silnika.

\section{Procedura badawcza}

Generator TEG zaimplementowano w układzie wylotowych silnika 1,3 JTD o zapłonie samoczynnym, pojemności skokowej 1,3 $\mathrm{dm}^{3}$, spełniającego normę emisji Euro 4 pomiędzy reaktorem katalitycznym a układem odprowadzenia gazów wylotowych ze stanowiska badawczego.

Generator umieszczono w części układu wylotowego, w której temperatura gazów wylotowych nie przekracza $300^{\circ} \mathrm{C}$ ze względu na nominalny zakres temperatur, w którym pracują zastosowane moduły BiSb/BiTe (tab. 1).

Układ silnik ZS-generator TEG przebadano na silnikowym stanowisku hamulcowym (rys. 5) wyposażonym w hamownię firmy Automex, przepływomierz powietrza ABB SensyFlow oraz dwa czujniki ciśnienia UMT 65, które mierzyły spadki ciśnienia. Rozkład temperatury wzdłuż wymiennika ciepła mierzono przy użyciu termopar zaimplementowanych w pobliżu gorących i zimnych stron elementów termoelektrycznych. Natężenie przepływu czynnika chłodzącego oraz jego temperaturę na wlocie i wylocie z chłodnic zmierzono w celu obliczenia ilości ciepła odebranego przez wymiennik ciepła. Napięcia i natężenia na każdym z odcinków elektrycznych mierzono oddzielnie.

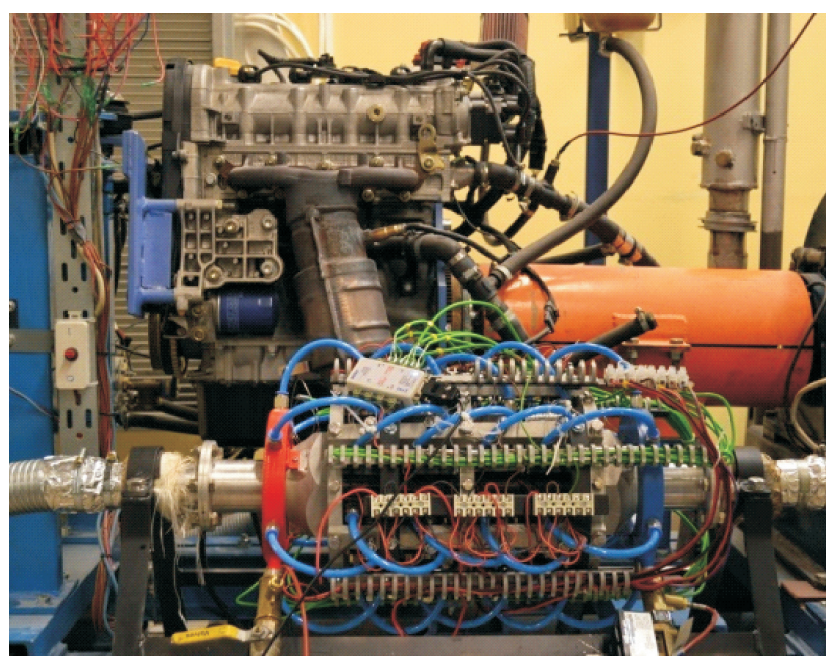

Fig. 5. Thermoelectric generator TEG during tests on the engine test cell Rys. 5. Generator termoelektryczny TEG podczas badań na silnikowym stanowisku hamulcowym

Badania generatora TEG przeprowadzono w zakresie prędkości obrotowej wału korbowego i obciążenia silnika (1800-2600 obr/min, 12-135 N·m) zbliżonym do zakresu pracy silnika w rzeczywistych warunkach eksploatacji. Charakterystykę silnika przedstawiono w tabeli 2. 


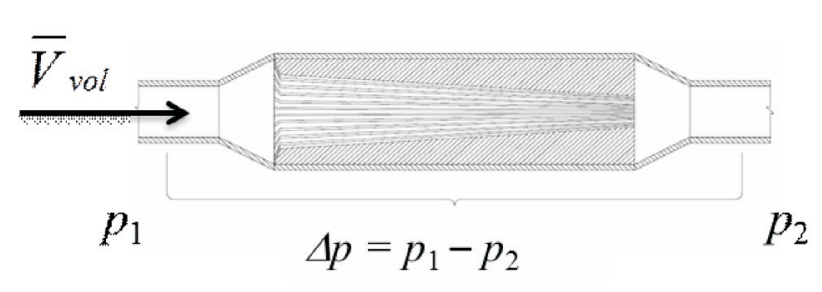

Fig. 6. Pressure drop on the TEG heat exchanger

Rys. 6. Spadek ciśnienia na wymienniku ciepła generatora TEG

of heat exchangers) and numerical method (finite-volume method). In both cases three-dimensional heat exchanger with turbulent, fully developed, and steady flow conditions at inlet was modelled. The calculations were made for air at temperature of $19^{\circ} \mathrm{C}$ with mass flow similar to the conditions in the exhaust system of a $1.3 \mathrm{dm}^{3}$ JTD engine.

In the analytical model a simplified geometry and DarcyWeisbach equations were applied. The heat exchanger was divided into 3 parts: diffuser, heat exchange chamber and convergent cone. It was assumed that the total flow resistance is the sum of the resistances of all the elements mentioned above. It allowed the estimation of the impact of the most important elements of the heat exchanger on total flow resistance. The precise description of this method is presented elsewhere [5].

The numerical analysis was performed with the use of ANSYS Workbench 14.0 which is a professional platform for advanced engineering simulations. The mesh was prepared in ANSYS Meshing program and flow simulation was performed in ANSYS Fluent software.

The geometry of the TEG was simplified to the inlet pipe, diffuser, and the heat exchange chamber in form of the pipe with $100 \mathrm{~mm}$ diameter, convergent cone and outlet pipe. The lengths of pipes connected to the TEG inlet and outlet were extended to 10 pipe diameters in order to obtain a fully developed inflow and to avoid the influence of external conditions on the outflow. The mesh was made with the fine boundary layer to capture the flow separation and wall effects. The volume of elementary cells ranged between $2.8 \cdot 10^{-9} \mathrm{~m}^{3}$ and $8.4 \cdot 10^{-8} \mathrm{~m}^{3}$, the skewness of the mesh was below 0.9 .

The pressure based model with absolute velocity formulation was selected for the solver procedure (Fluent software). For the viscosity calculations two-equation eddy-viscosity SST k- $\varepsilon$ model was used. By using this model high accuracy boundary layer simulations can be performed and the model is suitable for separated flows. Walls of the exchange chamber had no slip shear conditions defined.

Boundary conditions were: the inlet velocity (velocity $21.6 \mathrm{~m} \cdot \mathrm{s}^{-1}$ ) and the outlet pressure (gauge pressure 1000 $\mathrm{Pa}+$ atmospheric pressure of $101325 \mathrm{~Pa}$ ). For determining the turbulence at the boundary two additional parameters were taken into account: the turbulent intensity (4\%) and hydraulic diameter $(0.048 \mathrm{~m})$.

In the solution the pressure-velocity coupling method with SIMPLE algorithm was used. Due to convergence

\section{Teoretyczne obliczenia oporu przepływu gazów wylotowych}

Przeprowadzone badania wykazały, że generator TEG zainstalowany w układzie wylotowym silnika powoduje zwiększenie oporu przepływu gazów wylotowych i ma bezpośredni wpływ na spadek jego mocy. Opór przepływu gazu przez wymiennik ciepła może być określony na podstawie różnicy ciśnień gazów wylotowych przed i za generatorem TEG (rys. 6).

Straty mocy związane ze spadkiem ciśnienia obliczane są przy użyciu równania (3).

Opory przepływu oszacowano przy użyciu dwóch metod: przy zastosowaniu typowych wzorów algebraicznych, które są powszechnie stosowane do modelowania wymienników ciepła oraz za pomocą obliczeń numerycznych (metoda objętości skończonych). W obu przypadkach wykonano obliczenia dla trójwymiarowego modelu wymiennika ciepła z turbulentnym, rozwiniętym oraz stacjonarnym przepływem gazów wylotowych na wlocie do generatora TEG. Obliczenia przeprowadzono dla gazów o temperaturze $19{ }^{\circ} \mathrm{C}$ oraz masowym natężeniu przepływu podobnym do tego, jakie występuje w układzie wylotowym silnika 1,3 JTD.

W modelu analitycznym użyto uproszczonej geometrii oraz równań Darcy Weisbacha. Wymiennik ciepła podzielono na trzy części: dyfuzor, komora wymiany ciepła oraz konfuzor. Założono, że całkowity opór przepływu jest sumą trzech składowych opisanych powyżej. Pozwoliło to na wyznaczenie wpływu najważniejszych elementów wymiennika ciepła na całkowity opór przepływu. Dokładny opis tej metody zaprezentowano w pracy [5].

Analizę numeryczną przeprowadzono przy użyciu pakietu ANSYS Workbench 14.0, który służy do zaawansowanych symulacji inżynierskich. Siatkę wykonano w programie ANSYS Meshing natomiast modelowanie przepływu przeprowadzono przy użyciu programu ANSYS Fluent.

W celu uproszczenia obliczeń geometrię układu generatora TEG zredukowano do najważniejszych elementów: tj. przewodu wlotowego, dyfuzora oraz komory wymiany ciepła mającej postać walca o średnicy $100 \mathrm{~mm}$, konfuzora oraz przewodu wylotowego. Przewody doprowadzające do wlotu i wylotu generatora TEG miały ustaloną długość 10 średnic, w celu osiągnięcia w pełni rozwiniętego przepływu gazów wylotowych oraz w celu uniknięcia wpływu warunków zewnętrznych na zachowanie gazów na wylocie z generatora. W celu precyzyjnego określenia separacji przepływu przy ściankach obiektu warstwę przyścienną siatki modelu odpowiednio zagęszczono. Objętość komórek elementarnych mieściła się $\mathrm{w}$ granicach od $2,8 \cdot 10^{-9} \mathrm{~m}^{3}$ do $8,4 \cdot 10^{-8} \mathrm{~m}^{3}$, skośność siatki była poniżej 0,9 .

W procedurze rozwiązywania równań w programie Fluent zastosowano model optymalizacji ciśnienia lub wartości bezwzględnego przepływu. Do obliczeń lepkościowych użyto dwurównaniowego modelu SST k- $\varepsilon$. Według autorów programu przy użyciu tego modelu można osiągnąć dużą dokładność symulacji warstwy granicznej oraz separacji płynu. Na ściankach wymiennika ciepła założono brak tarcia gazu. 
problems some of the default under-relaxation factors (URF) were changed: momentum URF to 0.2 and pressure URF to 0.9 . For the first couple of iterations the second order upwind discretization scheme was applied. When the residuals began to oscillate it was necessary to decrease the discretization model to the first order. The convergence was assumed to be reached when the values of all residuals decreased below $10^{-5}$.

The next step of the research was the analysis of the independency of the results from the parameters of the mesh. For that purpose velocity gradient adaptation procedure was performed until the value of pressure drop was stabilized.

\section{Results}

The results are divided into two parts: results of power losses investigation and results of the TEG and modules performance. Additionally the concepts of additional improvements of the TEG performance are presented.

\section{Flow resistance investigation}

Figure 7 shows experimental results of pressure drop caused by thermoelectric generator fitted in exhaust system of the 1.3 JTD engine. The pressure drop ranges between 15 and $35 \mathrm{hPa}$ for mass flows of exhaust gases between 0.03 to $0.05 \mathrm{~kg} \cdot \mathrm{s}^{-1}$. The pressure drop does not seem to be very high in comparison to those occurring in other elements e.g. muffler, catalytic converter or DPF filter. It was calculated that power losses caused by the flow resistance of air with temperature of $19^{\circ} \mathrm{C}$ ranges from 6 to $20 \mathrm{~W}$ (Fig. 9). However, for hot exhaust gases $\left(200^{\circ} \mathrm{C}-250^{\circ} \mathrm{C}\right)$ the power losses increase to about 70-230 W. Therefore, in case of conditions with high power losses (high mass flow and high temperature) the feasibility of using a thermoelectric genera-

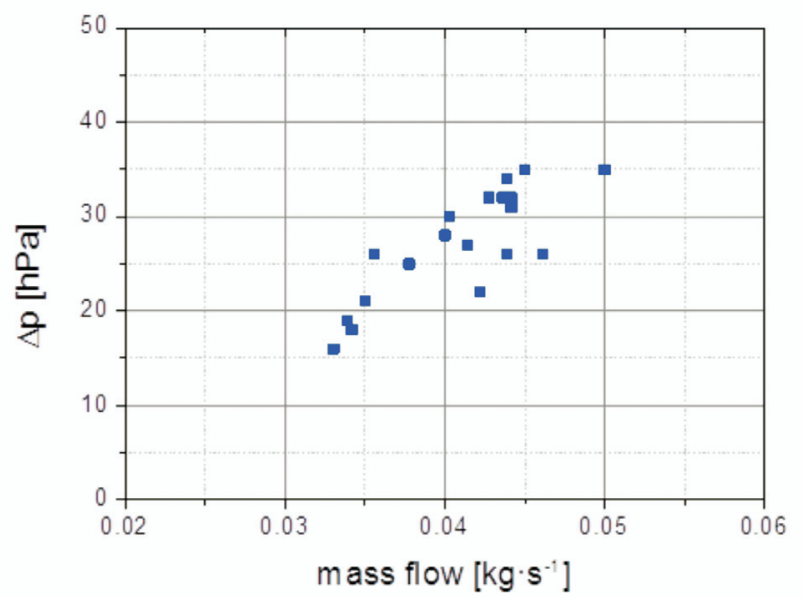

Fig. 7. The dependence of pressure drop on mass flow of exhaust gasses caused by TEG generator mounted in exhaust system of the 1.3 JTD engine. The experimental data are gathered for exhaust gases at $\mathrm{T}_{\text {in }}$ ranging from $200{ }^{\circ} \mathrm{C}$ to $250{ }^{\circ} \mathrm{C}$ at various engine rates (2125 to 3700 $\mathrm{rpm})$ and load torques $(12$ to $126 \mathrm{~N} \cdot \mathrm{m})$

Rys. 7. Zależność spadku ciśnienia od masowego natężenia przepływu gazów wylotowych dla generatora TEG zaimplementowanego $w$ uktadzie wylotowym silnika 1,3 JTD. Dane doświadczalne zestawiono dla gazów wylotowych o $T_{\text {in }} w$ granicach od $200{ }^{\circ} \mathrm{C}$ do $250{ }^{\circ} \mathrm{C}$ różnej prędkości obrotowej watu korbowego silnika (2125-3700 obr/min) i różnych momentach obrotowych $(12-126 \mathrm{~N} \cdot \mathrm{m})$
Warunkami brzegowymi były: prędkość na wlocie (prędkość $21,6 \mathrm{~m} \cdot \mathrm{s}^{-1}$ ) oraz ciśnienie na wylocie (nadciśnienie $1000 \mathrm{~Pa}+$ ciśnienie atmosferyczne $101325 \mathrm{~Pa}$ ). Do określenia przepływu turbulentnego użyto dwóch parametrów: intensywności turbulencji (4\%) oraz średnicy hydraulicznej $(0,048 \mathrm{~m})$.

W rozwiązaniu użyto sprzężonej metody ciśnienie-prędkość wraz z algorytmem SIMPLE. Z powodu problemów ze zbieżnością podczas iteracji niektóre domyślne wartości współczynników relaksacyjnych (URF) zostały zmienione: pęd URF na 0,2 oraz ciśnienie URF na 0,9. Podczas pierwszych kilku iteracji stosowano procedurę dyskredytacji drugiego rzędu, następnie gdy wartości wariancji resztowej zaczęły oscylować zmniejszono sposób dyskredytacji do pierwszego rzędu. Założono, że zbieżność została osiągnięta, gdy wszystkie wariancje resztowe wszystkich parametrów spadły poniżej wartości $10^{-5}$.

Kolejnym etapem badań była analiza niezależności wyników od wykonanej siatki. W tym celu wykonywano adaptację siatki na podstawie gradientu prędkości, aż do momentu, w którym wartość spadku ciśnienia na wymienniku ciepła generatora TEG się ustabilizowała.

\section{Wyniki badań}

Wyniki przeprowadzonych prac podzielono na dwie części: wyniki analizy oporów przepływu oraz wyniki wydajności modułów generatora TEG. Zaprezentowano także koncepcje dodatkowych ulepszeń generatora.

\section{Badanie oporów przepływu}

$\mathrm{Na}$ rysunku 7 przedstawiono wyniki eksperymentalne spadku ciśnienia spowodowanego prze generator termoelektryczny zainstalowany w układzie wylotowym silnika 1,3 JTD. Spadek ciśnienia mieści się w zakresie 15-35 hPa dla masowego natężenia przepływu gazów wylotowych w granicach od 0,03 do $0,05 \mathrm{~kg} \cdot \mathrm{s}^{-1}$. Spadek ciśnienia nie jest wysoki w porównaniu ze spadkami występującymi na innych elementach układu wylotowego, np. tłumik, reaktor katalityczny albo filtr cząstek stałych. Stwierdzono, że straty mocy spowodowane przez opór przepływu powietrza w temperaturze $19{ }^{\circ} \mathrm{C}$ mieszczą się w granicach 6-20 W (rys. 9). Jednakże, dla gazów wylotowych o temperaturze 200-250 ${ }^{\circ} \mathrm{C}$ straty mocy zwiększają się do ok. 70-230 W. W związku z tym, w przypadku warunków tworzących duże straty mocy (wysokie natężenie przepływu oraz wysoka temperatura) słuszność użycia generatora termoelektrycznego staje się wątpliwa. Z tego względu przeprowadzono dalsze badania określające przyczyny powstawania strat ciśnienia.

Analizę rozpoczęto od numerycznej symulacji przepływu gazów wylotowych w wymienniku ciepła. Na rysunku przedstawiono obliczoną mapę wektorów prędkości gazu w wymienniku ciepła TEG.

Na podstawie powyższych zależności stwierdzono, że w miejscu, w którym przewód wlotowy zaczyna się rozszerzać następuje separacja strugi gazu od ścianki dyfuzora. Separacja przepływu powoduje straty energii, które zmniejszają sprawność dyfuzora. W kolejnych elementach, tj. komora 


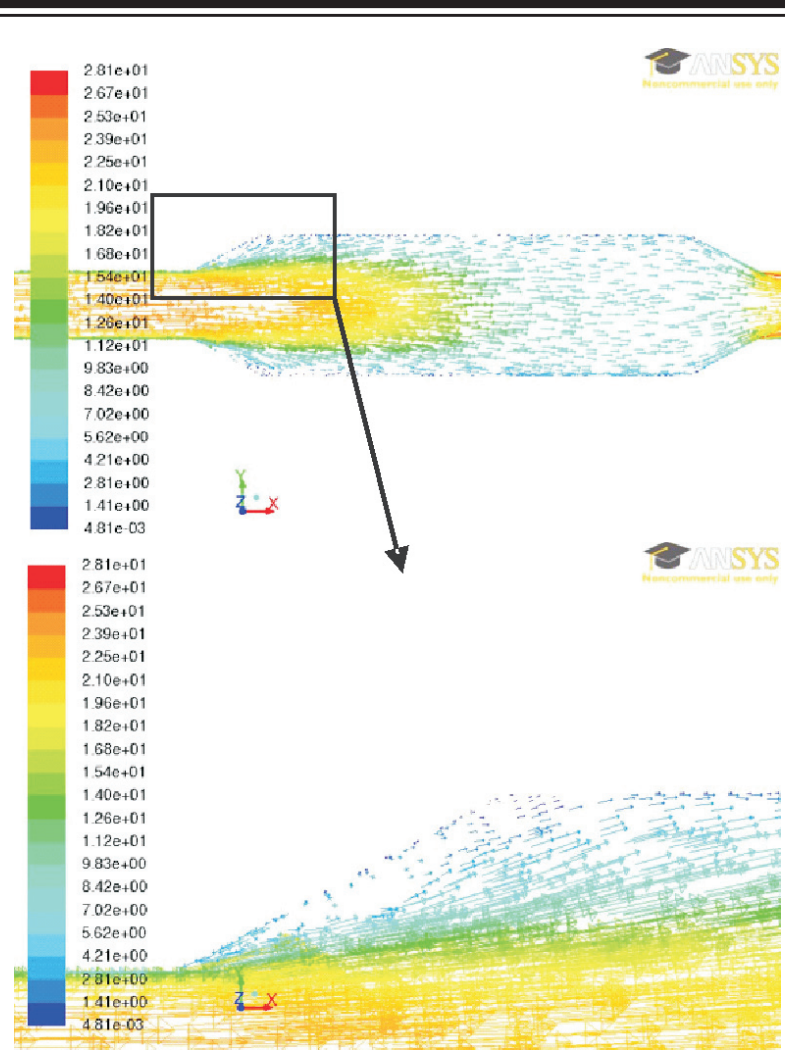

Fig. 8. Velocity vectors of gases in the heat exchanger of TEG Rys. 8. Wektory prędkości gazów w wymienniku ciepła generatora TEG

tor becomes questionable. For this reason further analyses of reasons of pressure losses were performed.

The investigation began from numerical simulation of the fluid flow in the heat exchange chamber. Figure 8 shows the calculated map of velocity vectors in the TEG heat exchanger.

It reveals that flow starts separating from the solid wall where the inlet pipe begins to diverge. Flow separation causes energy losses which further decrease the performance of the diffuser. However, in the next parts, i.e. heat exchange chamber and convergent cone, the gases flow separation is not observed. Clearly, on the basis of these numerical simulations, it can be concluded that the diffuser part of the heat exchanger is the main reason behind the power losses.

In order to estimate the contribution of each part of the HX on the total pressure drop theoretical calculations with the use of classical, analytical models were performed [5].

The analytical calculations confirmed the results of numerical simulations. Figure 9 shows that the diffuser's contribution in the total pressure drop $\Delta \mathrm{p}$ is the most significant; pressure losses caused by the convergent cone and the heat exchange chamber can be neglected.

High flow resistance of the diffuser can be explained by its large flare angle of $\alpha=57^{\circ}$. However, calculations have shown that pressure drop can be reduced by $2 / 3$ if the flare angle is lowered to $\alpha=5^{\circ}$ (see Fig. 10).

The evaluation of the correctness of the proposed model of flow resistances in the heat exchanger has been performed by the comparison of the theoretical results with the experi- wymiany ciepła oraz konfuzor, nie zaobserwowano separacji gazu. Na podstawie symulacji numerycznych stwierdzono, że dyfuzor jest główną przyczyną strat mocy w wymienniku ciepła.

W celu określenia wpływu poszczególnych elementów wymiennika ciepła na całkowity spadek ciśnienia wykonano teoretyczne obliczenia z wykorzystaniem typowych, analitycznych modeli [5].

Wykonane obliczenia potwierdziły wyniki symulacji numerycznych. Na podstawie zależności przedstawionych na rysunku 9 stwierdzono, że udział dyfuzora w całkowitym spadku ciśnienia jest największy; straty ciśnienia związane z oporami w komorze wymiany ciepła oraz konfuzorem moga zostać pominięte.

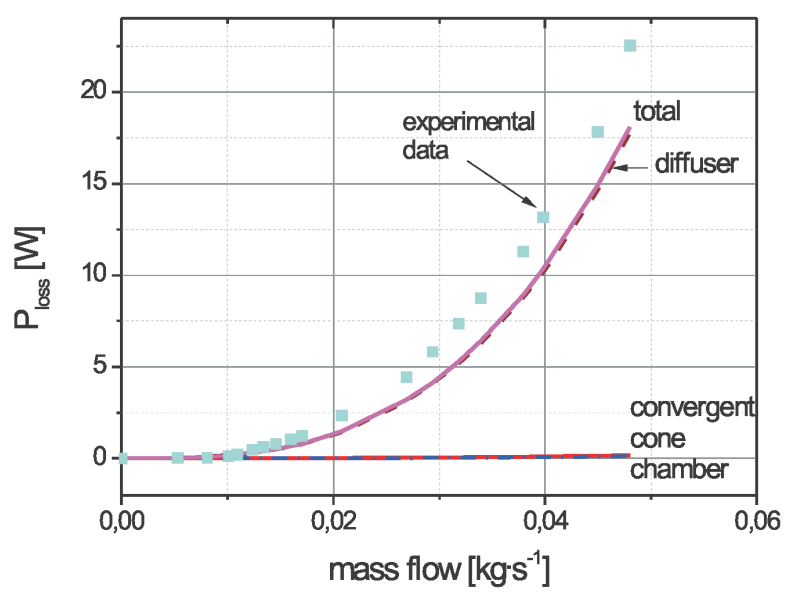

Fig. 9. Theoretical (solid lines) contribution of the main elements of the heat exchanger on total power losses caused by flow resistance of gases. The experimental data (dots) were gathered for air flowing at temperature of $\mathrm{T}_{\text {inp }}=19^{\circ} \mathrm{C}$

Rys. 9. Teoretyczny (linia ciagła) udział głównych elementów wymiennika ciepla w calkowitej stracie mocy spowodowanej oporami przeplywu gazów wylotowych. Dane eksperymentalne (kropki) zostały zebrane podczas przeptywu powietrza o temperaturze $T_{i n p}=19^{\circ} \mathrm{C}$

Spadek ciśnienia na dyfuzorze spowodowany był dużym kątem rozwarcia $\alpha=57^{\circ}$. Jednakże, obliczenia wykazały, że spadek ten może być zmniejszony o $2 / 3$, jeśli kąt rozwarcia zmniejszy się do wartości $\alpha=5^{\circ}$ (rys. 10).

Ocenę poprawność proponowanego modelu oporów przepływu w wymienniku ciepła przeprowadzono przez porównanie wyników teoretycznych z wynikami empirycznymi. Na rysunku 9 przedstawiono wyniki eksperymentu oraz obliczeń za wykonanych pomocą klasycznych metod analitycznych. Zaobserwowano, że model teoretyczny dobrze opisuje dane eksperymentalne. Małe niedoszacowanie całkowitego oporu można wytłumaczyć założonymi uproszczeniami dokonanymi w modelu.

Ponadto obliczenia wykazały, że w przypadku silników o zapłonie iskrowym, o mocy porównywalnej z mocą silnika 1,3 JTD, starty mocy związane z oporami przepływu mogą być znacznie mniejsze. Natężenie przepływu gazów wylotowych z silnika ZI jest 3-krotnie niższe niż w silnikach ZS. 
mental data. Figure 9 presents the results of the experiment and calculations using classical, analytical method. It can be observed that the theoretical model matches the experimental data quite well. Small underestimation of the total resistance can be explained by the assumed simplifications made in the model.

Furthermore, our rough calculations show that in case of spark ignition SI engines with power comparable to 1.3 JTD the power losses assigned to pressure drop can be much smaller. The gas flow in a SI engine is about 3-times lower that in the corresponding CI engine. It implicates about 10times lower flow resistance losses. These conclusions are consistent with our previous results [3].

The great advantage of the spark ignition engine is a consequence of its typically higher temperatures as well as lower flow rates of exhaust gases. However, maximum temperatures in the exhaust system of the SI engine exceed operating temperatures of applied BiTe - based thermoelectric modules. It is necessary to apply other materials with a higher temperature range of up to $400{ }^{\circ} \mathrm{C}$ in order to receive higher performance parameters.

\section{TEG and TE modules performance}

The Figure 11 shows experimental results of dependence of the TEG power $\mathrm{P}_{\text {TEG }}$ and efficiency $\eta_{\text {Tот }}$ on the mass flow of the exhaust gases.

The total generator's efficiency $\eta_{\text {Тот }}$ fits in the range from $1.1 \%$ to $1.9 \%$ and decreases significantly with the increase of the gas flow. We have found that the power of the generator in the examined engine work parameters range depends on the gas flow value only slightly. The main factor limiting the total efficiency of the TEG is the efficiency of the applied commercial thermoelectric modules. Our measurements showed that their maximum efficiency reaches about $3 \%$ for optimal load conditions (Fig. 13, $\mathrm{T}_{\mathrm{c}}=25^{\circ} \mathrm{C}, \mathrm{T}_{\mathrm{h}}=200$ ${ }^{\circ} \mathrm{C}, \mathrm{R}_{\text {load }}=\mathrm{R}_{\text {int }}$ according to Norton-Thevenin theorem). By using above results it can be estimated that efficiency of the heat exchanger ranges from about 50 to $70 \%$.

The TEG generator produces the maximum electrical

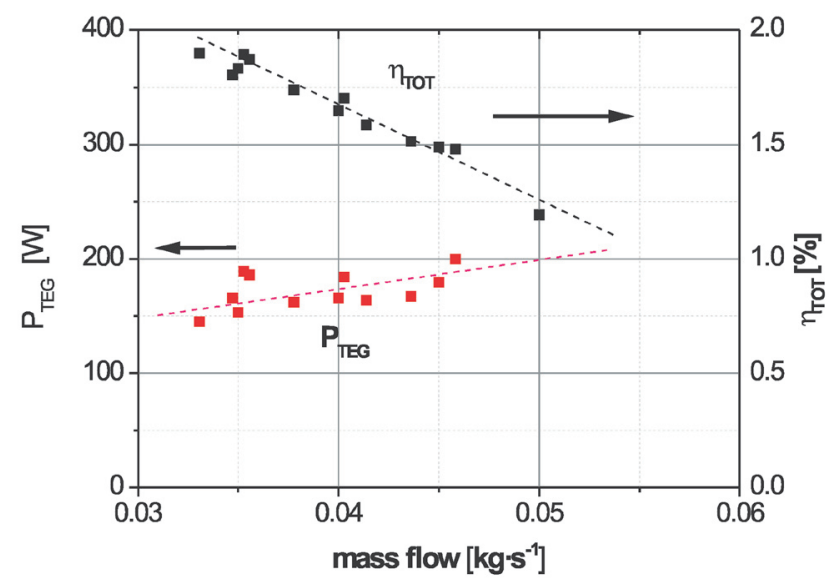

Fig. 11. Dependence of TEG power $\mathrm{P}_{\mathrm{TEG}}$ and total efficiency $\eta_{\text {Tот }}$ on mass flow of exhaust gases for the $1.3 \mathrm{JTD}$ engine $\left(\mathrm{T}_{\text {inp }}=235-290^{\circ} \mathrm{C}\right)$ Rys. 11. Zależność mocy generatora PTEG oraz calkowitej sprawności $\eta_{\text {тот }}$ od masowego natężenia przeptywu gazów wylotowych silnika $1.3 \operatorname{JTD}\left(T_{i n p}=235-290^{\circ} \mathrm{C}\right)$

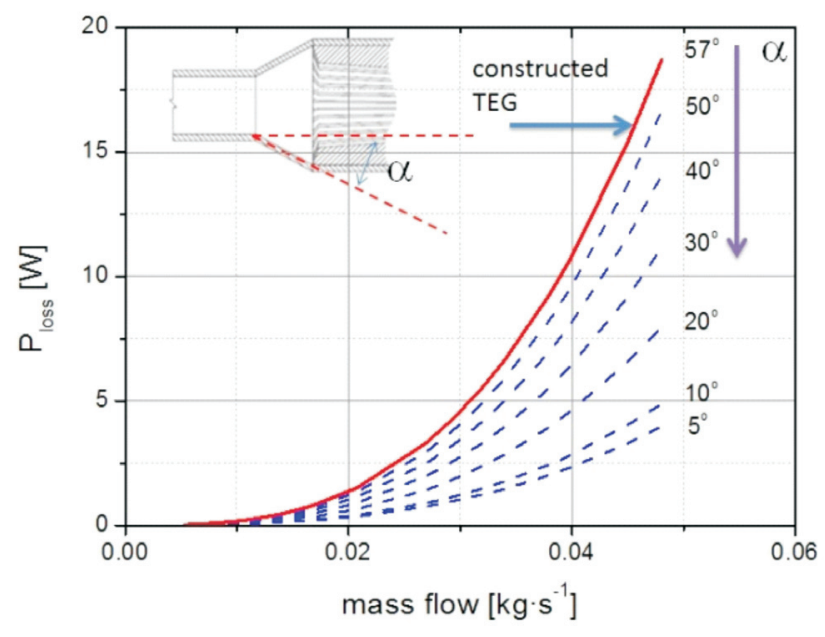

Fig. 10. Calculated dependence of power losses on the diffuser flare angle

Rys. 10. Wyliczona zależność strat ciśnienia od kąta rozwarcia dyfuzora

To implikuje 10-krotnie niższe opory przepływu. Wnioski te są zgodne z naszymi wcześniejszymi wynikami [3].

Zaletą użycia silnika o zapłonie iskrowym jest wysoka temperatura oraz niższe natężenie przepływu gazów wylotowych w porównaniu z silnikiem o zapłonie samoczynnym. Jednak maksymalna temperatura $\mathrm{w}$ układzie wylotowym silnika ZI przekracza zakres temperatury pracy zastosowanych modułów termoelektrycznych. W celu uzyskania dużej sprawności generatora TEG należy zastosować materiały TE, które posiadają wyższy zakres temperatur - do $400{ }^{\circ} \mathrm{C}$.

\section{Sprawność generatora TEG oraz modułów TE}

Na rysunku 11 przedstawiono wyniki badań empirycznych zależności mocy TEG $\mathrm{P}_{\mathrm{TEG}}$ oraz jego sprawności $\eta_{\text {TOT }}$ od masowego natężenia przepływu gazów wylotowych.

Całkowita sprawność $\eta_{\text {TOT }}$ generatora mieści się w zakresie 1,1-1,9 \% i zmniejsza się wraz ze wzrostem natężenia przepływu gazów wylotowych. Stwierdzono, że moc elektryczna generatora, w badanym zakresie parametrów pracy silnika, tylko nieznacznie zależy od natężenia przepływu gazów. Głównym czynnikiem wpływającym na całkowitą sprawność generatora TEG jest sprawność zastosowanych komercyjnych modułów termoelektrycznych. Pomiary wykazały, że ich maksymalna sprawność wynosi ok. $3 \%$ dla optymalnych warunków pracy (rys. $13, \mathrm{~T}_{\mathrm{c}}=25^{\circ} \mathrm{C}, \mathrm{T}_{\mathrm{h}}=$ $=200{ }^{\circ} \mathrm{C}, \mathrm{R}_{\text {load }}=\mathrm{R}_{\text {int }}$ dla warunków Nortona Thevenina). $\mathrm{Na}$ podstawie otrzymanych wyników badań stwierdzono, że sprawność wymiennika ciepła zawiera się w granicach $50-70 \%$.

Generator TEG generuje maksymalną moc elektryczną $\mathrm{P}_{\mathrm{TEG}} \cong 200 \mathrm{~W}$ dla temperatury gazów na wlocie $\mathrm{T}_{\mathrm{inp}}=290^{\circ} \mathrm{C}$ (rys. 13) oraz natężenia przepływu gazów wylotowych $165 \mathrm{~kg} / \mathrm{h}$. Optymalne warunki pracy osiągane są dla mocy silnika $\mathrm{P}_{\mathrm{e}}$ 20-30 kW.

\section{Sprawność modulów termoelektrycznych}

Na podstawie przeprowadzonych analiz stwierdzono, że parametry użytych modułów TE są kluczowe zarówno dla wydajności, jak i maksymalnej mocy TEG. W urządzeniu 
power $\mathrm{P}_{\mathrm{TEG}} \cong 200 \mathrm{~W}$ at the inlet gases temperature $\mathrm{T}_{\text {inp }}$ of about $290{ }^{\circ} \mathrm{C}$ (Fig. 12) and the gas flow of approximately $165 \mathrm{~kg} / \mathrm{h}$. The optimal working conditions are achieved for engine powers $\mathrm{P}_{\mathrm{e}}$ in the range from $20 \mathrm{~kW}$ up to $30 \mathrm{~kW}$.

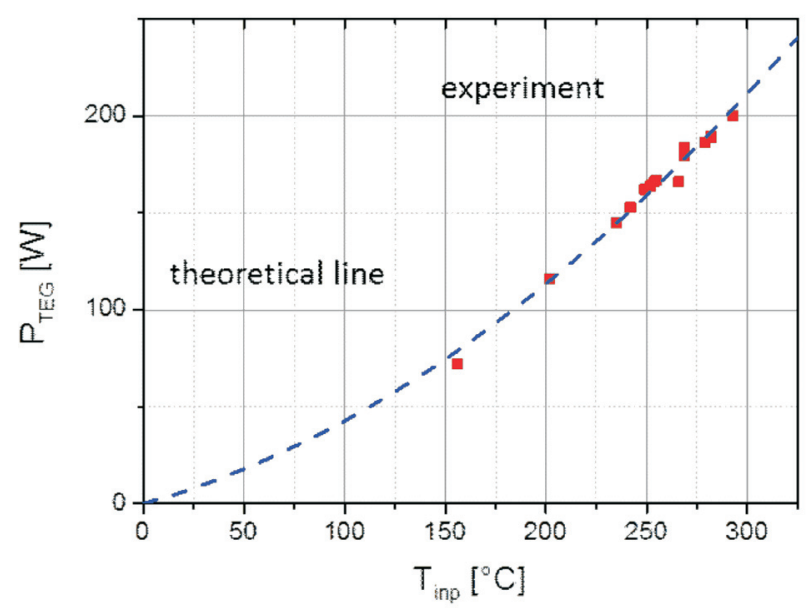

Fig. 12. Power $\mathrm{P}_{\mathrm{TEG}}$ of the TEG vs. temperature $\mathrm{T}_{\text {inp }}$ of gases on input (points - experimental results; dotted line - theoretical model)

Rys. 12. Moc generatora TEG $P_{T E G}$ w funkcji temperatury $T_{\text {inp }}$ gazów wylotowych na wejściu generatora (punkty - wyniki eksperymentu; linia przerywana - model teoretyczny)

\section{Efficiency of thermoelectric modules}

Our analyses show that parameters of used TE modules are crucial both for efficiency and maximum power of the TEG. In our device commercial $7 \mathrm{~W}$ Bi-Te modules for power generation were applied. According to datasheets of the producer these modules can operate in the temperature range from 20 to $175{ }^{\circ} \mathrm{C}$ with the maximum efficiency of about $4 \%$. However our tests revealed that their efficiency is slightly lower and reaches maximum value of about $3 \%$ (Fig. 13). According to the equation (1) increasing the hot side temperature $\mathrm{TH}$ should lead to the increase of TE modules' overall efficiency.

Investigations of temperature distribution in the exhausts system of the Diesel engine have shown that in place just behind the aftertreatment system temperatures of exhaust gases from 300 to $500{ }^{\circ} \mathrm{C}$ are available. However because

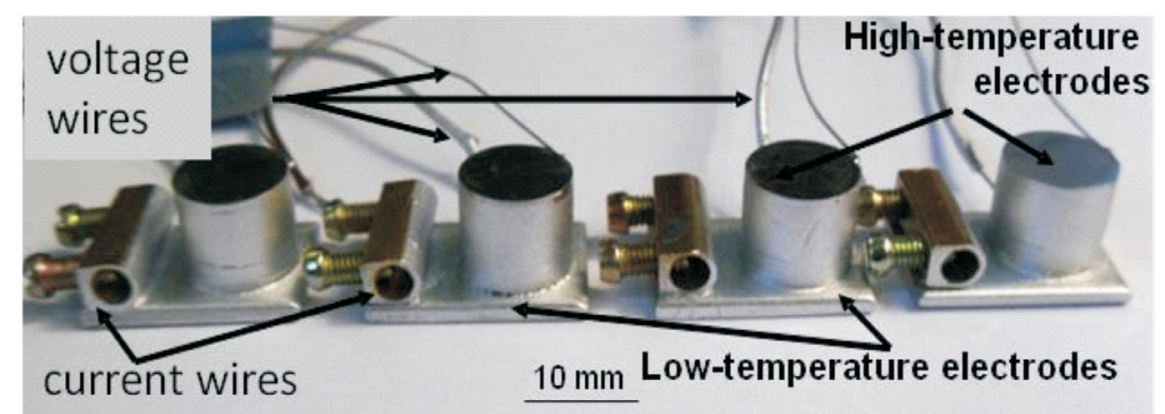

Fig.14 Segmented Bi2Te3/CoSb3 elements developed at the AGH University of Science and Technology

Rys. 14. Segmentowe elementy termoelektryczne Bi2Te3/CoSb3 opracowane w AGH do konwersji energii zastosowano komercyjne moduły $\mathrm{Bi}-\mathrm{Te}$ o mocy $7 \mathrm{~W}$. Zgodnie z danymi dostarczonymi przez producenta, moduły te mogą pracować w temperaturach $\mathrm{z}$ zakresu $20-175^{\circ} \mathrm{C}$, z maksymalną sprawnością wynoszącą ok. 4 \%. Jednak przeprowadzone badania wykazały, że ich sprawność jest niższa i wynosi maksymalnie $3 \%$ (rys. 13). Zgodnie z równaniem (1) wzrost temperatury po gorącej stronie TH powinien prowadzić do wzrostu całkowitej sprawności modułów TE.

Badania rozkładu temperatur w układzie wylotowym silnika ZS wykazały, że w miejscu tuż za reaktorem katalitycznym temperatury gazów wylotowych zmieniają się w

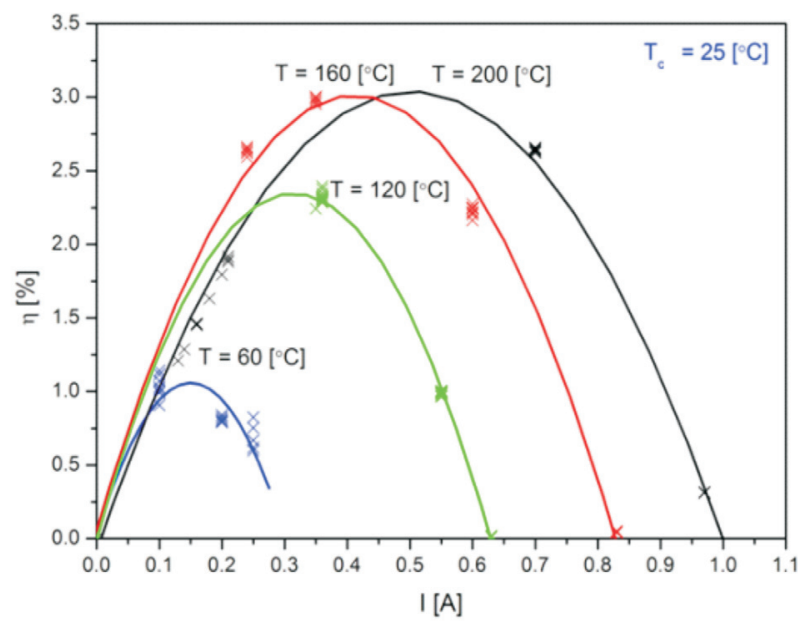

Fig. 13. Current-efficiency characteristics for the commercial module applied in TEG generator. $\left(\mathrm{T}_{\mathrm{C}}=25^{\circ} \mathrm{C} ; \mathrm{T}_{\mathrm{H}}=60-200{ }^{\circ} \mathrm{C}\right.$, points - experimental results; solid line - theoretical model)

Rys. 13. Charakterystyki prąd-sprawność komercyjnego modułu zastosowanego $w$ generatorze $\left(T_{C}=25^{\circ} \mathrm{C}, T_{H}=60-200^{\circ} \mathrm{C}\right.$; punkty - wyniki eksperymentalne; linia ciagła - model teoretyczny)

zakresie $300-500{ }^{\circ} \mathrm{C}$. Jednak z powodu ograniczeń temperaturowych materiałów termoelektrycznych zastosowanie komercyjnych modułów było niemożliwe.

Ostatnio w Laboratorium Badań Termoelektrycznych AGH opracowano prototypowe segmentowe moduły TE, które spełniają te warunki temperaturowe [6]. Nasze pierwsze moduły segmentowe posiadają maksymalną sprawność $\eta=9 \%$ (rys. 14-15), która jest dwa razy wyższa od najlepszych komercyjnych modułów $\mathrm{Bi}-\mathrm{Te}$, oraz posiadają 5-krotnie wyższą gęstość mocy. Przewidywane jest, że zastosowanie tych modułów w generatorze TEG umożliwiłoby wzrost jego mocy elektrycznej do $1 \mathrm{~kW}$.

\section{Wnioski}

Prototypowy generator termoelektryczny TEG do konwersji energii odpadowej generuje maksymalną moc $200 \mathrm{~W}$ dla gazów wylotowych o temperaturze na wlocie $\mathrm{T}_{\text {inp }}$ równej 
of temperature limits of the thermoelectric materials the application of the commercial modules is not possible.

However, recently we have developed prototypical segmented TE modules meeting these temperature conditions [6]. Our first segmented modules have the maximum efficiency of about $\eta=9 \%$ (Fig. 15), twice as high as of the best commercial BiTe modules and 5 -times higher power density. We predict that application of these modules in our generator would allow an increase of its electrical power to about $1 \mathrm{~kW}$.

\section{Conclusions}

The prototypical thermoelectric generator for waste heat recovery generates maximum power of $200 \mathrm{~W}$ at the inlet gases temperature $\mathrm{T}_{\text {imp }}$ of about $290{ }^{\circ} \mathrm{C}$ and the gas flow of approximately $165 \mathrm{~kg} / \mathrm{h}$. The optimal working conditions are achieved for engine powers Pe in the range from $20 \mathrm{~kW}$ up to $30 \mathrm{~kW}$. The pressure drop of exhaust gases caused by the heat exchanger of TEG ranges between 15 and $35 \mathrm{hPa}$ for mass flows between 0.03 to $0.05 \mathrm{~kg} \cdot \mathrm{s}^{-1}$. The pressure drop is neglectable in comparison to that of other elements of engines' exhaust systems e.g. muffler, catalytic converter or DPF filter. The total generator's efficiency $\eta_{\text {тот }}$ fits in the range from $1.1 \%$ to $1.9 \%$. According to our predictions, the power of the TEG generator can be increased up to $1 \mathrm{~kW}$ by application of new segmented thermoelectric elements developed at AGH University of Science and Technology. Such generator could have parameters sufficient for substitution of the car alternator. It could allow for the increase of about $5 \%$ of the overall efficiency of the powertrain, and a corresponding reduction of $\mathrm{CO}_{2}$ emission.

\section{Acknowledgements/Podziękowania}

The research was partially funded by the National Science Centre (Narodowe Centrum Nauki) - research project (contract No. UMO-2011/01/B/ST8/07241 and 2627/B/ T02/2011/40).

Badania sfinansowano ze środków Narodowego Centrum Nauki - projekt badawczy (umowa $n r$ UMO-2011/01/B/ ST8/07241 oraz umowa $n$ r 2627/B/T02/2011/40).

\section{Nomenclature/Skróty i oznaczenia}

TEG Thermoelectric generator/generator termoelektryczny

JTD uniJet Turbo Diesel

TE thermoelectric/termoelektryczny

HX heat exchanger/wymiennik ciepta

$\eta_{\text {gmax }}$ maximal efficiency of thermoelectric generator /maksymalna wydajność generatora termoelektrycznego

$\eta_{c} \quad$ Carnot efficiency/sprawność Carnota

ZT thermoelectric efficiency coefficient /współczynnik efektywnosci termoelektrycznej

$\mathrm{T}_{\mathrm{C}} \quad$ temperature of the theromoelectric module cold side/temperatura zimnej strony modulu termoelektrycznego

$\mathrm{T}_{\mathrm{H}} \quad$ temperature of the theromoelectric module hot side/temperatura cieptej strony modulu termoelektrycznego

$\alpha_{\mathrm{s}} \quad$ Seebeck coefficient/współczynnik Seebecka

$\sigma \quad$ electrical conductivity/przewodnictwo elektryczne wtaściwe

$\lambda$ thermal conductivity coefficient/współczynnik przewodzenia ciepta

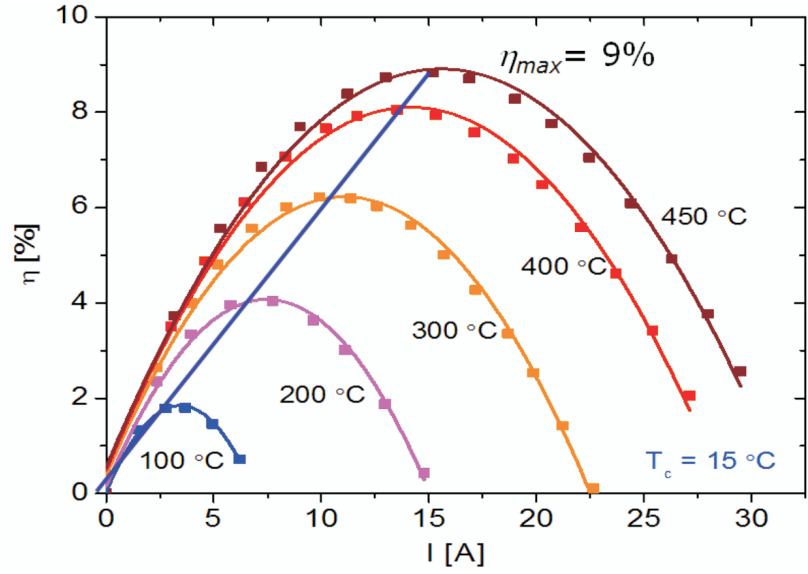

Fig. 15. Current-efficiency characteristics for the segmented element developed at the AGH University of Science and Technology $\left(\mathrm{T}_{\mathrm{C}}=15^{\circ} \mathrm{C}\right.$; $\mathrm{T}_{\mathrm{H}}=100-450^{\circ} \mathrm{C}$, points - experimental results; solid line - theoretical model)

Rys. 15. Charakterystyki prad-sprawność modulu segmentowego opracowanego na $A G H\left(T_{C}=15{ }^{\circ} \mathrm{C}, T_{H}=100-450^{\circ} \mathrm{C}\right.$; punkty - wyniki eksperymentu; linia ciagla - model teoretyczny)

$290{ }^{\circ} \mathrm{C}$ oraz natężeniu przepływu $165 \mathrm{~kg} / \mathrm{h}$. Optymalne warunki pracy osiągnięto dla mocy silnika $\mathrm{P}_{\mathrm{e}} \mathrm{w}$ zakresie 20-30 kW. Spadek ciśnienia gazów wylotowych spowodowany wymiennikiem ciepła TEG zawiera się w granicach 15-35 hPa dla masowego natężenia przepływu pomiędzy $0,03-0,05 \mathrm{~kg} \cdot \mathrm{s}^{-1}$. Spadek ciśnienia jest pomijalnie mały $\mathrm{w}$ porównaniu z innymi elementami układu wylotowego silnika, takimi jak: tłumik, reaktor katalityczny czy filtr cząstek stałych. Całkowita sprawność generatora $\eta_{\text {тот }}$ mieści się $\mathrm{w}$ zakresie od 1,1-1,9\%. Zgodnie z przewidywaniami, moc generatora TEG może zostać zwiększona do $1 \mathrm{~kW}$ dzięki zastosowaniu nowych segmentowych modułów termoelektrycznych opracowanych w Akademii Górniczo-Hutniczej w Krakowie. Taki generator posiadałby parametry wystarczające do zastąpienia alternatora w samochodzie. Pozwoliłby to na $5 \%$ wzrost całkowitej sprawności układu napędowego, i odpowiednie zmniejszenie emisji $\mathrm{CO}_{2}$.

$\mathrm{V}_{\mathrm{vol}}$

average volumetric flow rate/średnie objętościowe natężenie przepływu

$\mathrm{p}_{1} \quad$ absolute pressure on the TEG inlet/ciśnienie absolutne na wlocie do TEG

$\mathrm{p}_{2} \quad$ absolute pressure on the TEG outlet/ciśnienie absolutne na wylocie z TEG

$\Delta \mathrm{p} \quad$ pressure drop caused by the TEG heat exchanger/gaz skroplony

$\mathrm{P}_{\text {loss }} \quad$ power loss/strata mocy

$\mathrm{T}_{\text {inp }}$ gas temperature at the TEG inlet/temperatura gazu na wlocie do TEG

a flare angle of the diffusor/kat rozwarcia dyfuzora

$\mathrm{P}_{\mathrm{TEG}} \quad$ power produced by TEG/moc uzyskana z TEG

$\eta_{\text {тот }}$ TEG efficiency/wydajność TEG

$\mathrm{P}_{\mathrm{e}} \quad$ engine power/moc silnika

$\eta_{\max }$ maximal, real efficiency of the thermoelectric module/ maksymalna rzeczywista wydajność modułu termoelektrycznego 


\section{Bibliography/Literatura}

[1] Vazaquez J., Zanz-Bobi M. A, Palacios R., Arenas A.: State of the art of thermoelectric generators based on heat recovered from the exhaust gases of automobiles. Proc. of 7th European Workshop on Thermoelectrics, Pamplona, Spain, 2002.

[2] Birkholz U., et al.: Conversion of waste exhaust heat in automobile using FeSi2 thermoelements. Proc. 7th International Conference on Thermoelectric Energy Conversion, Arlington, USA, pp.124-128, 1988.

[3] Wojciechowski K.T. ,Schmidt M., Zybala R., Merkisz J., Fuć P., Lijewski P.: Comparison of waste heat recovery from the exhaust of a spark ignition and a diesel engine. Journal of Electronic Materials, Volume 39, Issue 9, pp.2034, 2010.

[4] Bass, J., Elsner, N. B. and Leavitt, A.: Performance of the 1 $\mathrm{kW}$ thermoelectric generator for diesel engines. Proc. 13th Int.
Conf. Thermoelectrics B, Mathiprakisam, edn., AIP Conf. Proc., New York, No. 295, 1995.

[5] Wojciechowski K. T., Zybala R., Tomankiewicz J., Fuc P., Lijewski P., Wojciechowski J., Merkisz J.: Influence of back pressure on net efficiency of TEG generator mounted in the exhaust system of a diesel engine. Thermoelectrics Goes Automotive II (Thermoelectrics III), expert verlag, Germany, pp. 177-188, 2013.

[6] Wojciechowski K. T., Zybala R., Leszczynski J., Nieroda P., Schmidt M., Gajerski R., Aleksandrowa S.: Performance characterization of high-efficiency segmented Bi2Te3/CoSb3 unicouples for thermoelectric generators. AIP Conf. Proc. Series 1449, Melville, New York, pp. 467-470, 2012.
Wojciechowski Krzysztof T., DSc, DEng. - associate professor, Faculty of Materials Science and Ceramics at AGH University of Science and Technology.

Dr hab. inz, prof. AGH Krzysztof T. Wojciechowski - Wydzial Inżynierii Materiałowej i Ceramiki $A G H$.

e-mail: gcwojcie@cyf-kr.edu.pl

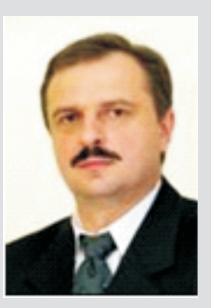

Tomankiewicz Joanna, MSc, Eng. - student in the Faculty of Materials Science and Ceramics at AGH University of Science and Technology.

Mgr inż. Joanna Tomankiewicz - studentka na Wydziale Inżynierii Materialowej i Ceramiki AGH. e-mail: j.tomankiewicz@gmail.com

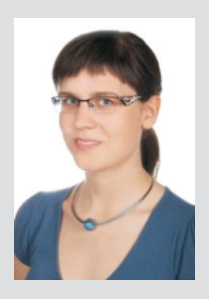

Zybala Rafal, MEng. - PhD student in the Faculty of Materials Science and Ceramics at AGH University of Science and Technology.

Mgr inż. Rafał Zybała - doktorant na Wydziale Inżynierii Materiałowej i Ceramiki AGH. e-mail: zybala@agh.edu.pl

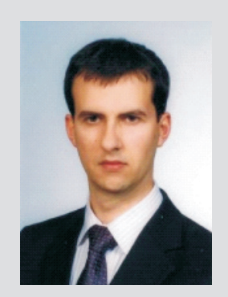

Leszczyński Juliusz, DEng. - doctor in the Faculty of Materials Science and Ceramics at AGH University of Science and Technology.

Dr inż. Juliusz Leszczyński - asystent na Wydziale Inżynierii Materiałowej i Ceramiki AGH. e-mail: jleszczy@poczta.onet.pl

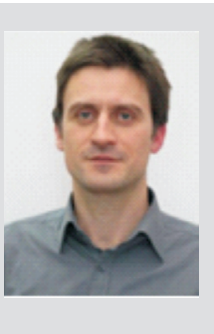

Prof. Merkisz Jerzy, DSc, DEng. - professor, Institute of Combustion Engines and Transport at Poznan University of Technology.

Prof. dr hab. inż. Jerzy Merkisz - profesor w Instytucie Silników Spalinowych i Transportu Politechniki Poznańskiej.

e-mail: jerzy.merkisz@put.poznan.pl

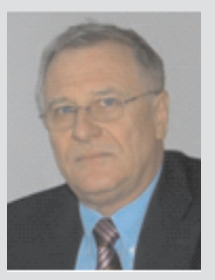

Fuć Paweł, DEng. - doctor, Institute of Combustion Engines and Transport at Poznan University of Technology.

Dr inż. Pawel Fuć - adiunkt w Instytucie Silników Spalinowych i Transportu Politechniki Poznańskiej.

e-mail:pawel.fuc@put.poznan.pl

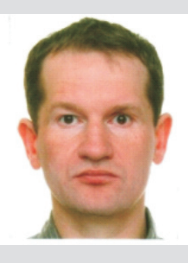

Lijewski Piotr, DEng. - doctor, Institute of Combustion Engines and Transport at Poznan University of Technology.

Dr inż. Piotr Lijewski - adiunkt w Instytucie Silników Spalinowych i Transportu Politechniki Poznańskiej.

e-mail: piotr.lijewski@put.poznan.pl

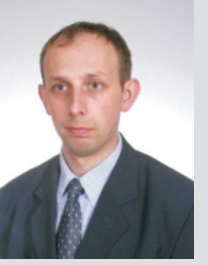

Nieroda Pawel, MEng. - PhD student in the Faculty of Materials Science and Ceramics at AGH University of Science and Technology.

Mgr inż. Pawet Nieroda - doktorant na Wydziale Inżynierii Materiałowej i Ceramiki AGH.

e-mail:pnieroda@agh.edu.pl

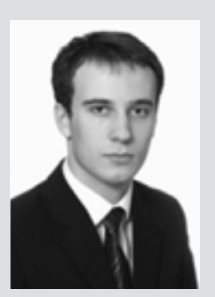

